\title{
SDHD gene mutation in Mexican population with carotid body tumor
}

\author{
Mutación del gen SDHD en población mexicana con tumor del cuerpo carotídeo
}

María Elizabeth Enríquez-Vega ${ }^{1 *}$, Jimena Gabriela Muñoz-Paredes ${ }^{1}$, Alfonso Cossío-Zazueta², Yam Ontiveros-Carlos ${ }^{3}$, Ernesto Pacheco-Pittaluga ${ }^{1}$ and Héctor Bizueto-Rosas ${ }^{1}$

${ }^{1}$ Department of Angiology and Vascular Surgery, Specialty Hospital; ${ }^{2}$ Division of Surgery; ${ }^{3}$ Division of Genetics. Hospital General Centro Médico la Raza IMSS. Mexico City. Mexico

\begin{abstract}
Introduction: Among the U.S. population, the p81L SDHD (11q23) gene mutation is present in 6-36\% of patients with sporadic carotid body tumor (CBT), but in familial cases is high as $80 \%$. That is why the P81L mutation is used as a screening method for carotid body tumor in the U.S. Methods: We included 25 patients who underwent resection of a CBT from January 2010 to June 2015. After informed consent, a blood sample was taken for genetic testing on real-time polymerase chain reaction, in order to identify p81L mutation in the SDHD gene. The information was analyzed with descriptive statistics, using central tendency and description measures. Results: In our group, 92\% were females, a mean age of 55.5 years, and $52 \%$ were Shamblin type II. The most common place of residence was Mexico City, $8 \%$ of the patients had family history, about $20 \%$ of the patients had a contralateral tumor and $16 \%$ had antecedent of another kind of tumor, 4 (16\%) p81L SDHD gene mutations were detected, all of them were heterozygous. Conclusions: The p81L mutation in the SDHD gene was found in the Mexican population in higher grade that in the U.S. population, which explain the high incidence of this pathology in our country, but we need more studies about this subject.
\end{abstract}

KEY WORDS: Carotid body tumor. SDHD gene. p81L mutation.

\section{Resumen}

Introducción: La mutación p81L del gen SDHD (11q23) se encuentra presente en el 6-36\% de los pacientes con tumores del cuerpo carotídeo (TCC) esporádicos y hasta en el $80 \%$ de los que presentan TCC familiares. En los EE.UU. se usa como método de cribado para TCC. Método: Se incluyeron 25 pacientes consecutivos operados de resección de TCC entre enero de 2010 y junio de 2015. Se les tomó muestra sanguínea venosa que se sometió a reacción en cadena de la polimerasa en tiempo real para identificar la mutación p81L del gen SDHD (11q23). La información se analizó con estadística descriptiva mediante medidas de tendencia central y dispersión. Resultados: Del grupo en estudio, el 92\% eran mujeres, la edad promedio era de 55.5 años y el 52\% tenían tumor Shamblin tipo II. El lugar de residencia más frecuente fue la Ciudad de México. El $8 \%$ presentaban antecedentes familiares, el 20\% tumor bilateral y el 16\% presentaron un tumor en otra región. Se encontró la mutación p81L del gen SDHD (11q23) en el 16\% de los pacientes de forma heterocigota. Conclusiones: La mutación p81L del gen SDHD se encuentra presente en la población mexicana en un grado más elevado que lo reportado en los EE.UU., lo que podría explicar la alta incidencia en nuestro medio.

PALABRAS CLAVE: Tumor del cuerpo carotideo. Gen SDHD. Mutación p81L.

\author{
Correspondence: \\ *María Elizabeth Enríquez-Vega \\ Seris y Zaachila, s/n \\ Col. La Raza, Del. Azcapotzalco \\ C.P. 02990, Ciudad de México, México \\ E-mail: elisa_angio@yahoo.com
}

Date of reception: 02-12-2017

Date of acceptance: $14-02-2018$

DOI: $10.24875 /$ CIRUE.M18000005
Cir Cir. 2018;86:33-37

Contents available at PubMed www.cirugiaycirujanos.com 


\section{Introduction}

Carotid body tumor (CBT), also known as paraganglioma, chemodectoma and carotid glomus, is a tumor originating in the ectoderm of the neural crest, and is classified into chromaffin and non-chromaffin cell-type.

Chromaffin cells have the ability to produce catecholamines, and are located from the base of the skull to the pelvic floor. Chromaffin cell paragangliomas are extremely rare, with an incidence of $0.03 \% \%^{1-3}$.

The most common localization of paragangliomas is the carotid body, where they account for $65 \%$ of all paragangliomas. They can be located less often in the jugular vein and the vagus nerve ${ }^{4}$. The carotid body is a sub-adventitial chemoreceptor located at the bifurcation of the primitive carotid artery on its posteromedial side; tumors deriving from this tissue are highly vascularized ${ }^{1,3-6}$

According to the Shamblin classification, CBTs are differentiated into three anatomical groups according to their size and surgical-technical difficulty ${ }^{7}$ :

- Type I: relatively small tumors, minimally adhered to the medial aspect of the carotid vessels. Surgical extirpation is simple.

- Type II: they involve and surround the internal and external carotid arteries, but do not go beyond their external boundaries.

- Type III: are very large tumors that surround the carotid arteries, extend beyond their lateral boundaries and can infiltrate the base of the skull. They also involve different nerves at the level of the neck and may require interposition of a graft with en block resection.

The treatment of choice is surgical resection, although another therapeutic option in large CBTs is embolization prior to the surgical procedure; these tumors are not radiosensitive ${ }^{8}$.

The male/female ratio reported in the Anglo-Saxon literature is 1:1.9 on average; however, in Latin America it is much more common in women, with a ratio of up to $1: 11^{3,5.6}$.

The reported incidence of this tumor in Latin America is among the highest. In the Oncology Hospital of the Siglo XXI National Medical Center (CNM - Centro Médico Nacional), 98 cases have been reported in 20 years $^{6}$; in the Specialty Hospital of the Siglo XXI CMN, 92 cases in 25 years ${ }^{9}$; and in the National Institute of Cancerology, 66 cases in 20 years $^{10}$. In Bolivia, 333 patients have been treated in 35 years ${ }^{5}$.
An altitude of residence higher than $1500 \mathrm{~m}$ above sea level is a known risk factor for chronic hypoxia, which induces hypertrophy of the carotid body. CBT is common in inhabitants of cities that are located at high altitudes above sea level, and cases can be sporadic or familial ${ }^{3,11}$.

Recent reports have found genetic mutations in up to one third of patients with paragangliomas. The most commonly involved genes are SDHD (PGL1), SDHB (PGL4) and SDHC (PGL3) $)^{12-14}$.

The SDH genes participate in oxidative phosphorylation, signaling and oxygen detection, which are part of mitochondrial complex II (also known as oxide-reductase succinate-ubiquinone) $)^{12,14}$. SDHD in chromosome 11q23 is the one most commonly associated with the pathogenesis of paragangliomas of the head and neck, while SDHB in chromosome 1p35-36 has been associated with malignancy or with the presence of extra-adrenal paragangliomas ${ }^{13-15}$. In the USA, $9 \%$ of cases have a familial component, whereas in the Netherlands this can be as high as $50 \%{ }^{16}$.

The SDHD gene is composed of four exons and encodes a 159-amino acid protein. Its function is to encode the anchoring subunit for ubiquinone binding, in order for electrons to be transferred from the iron-sulfur groups within the SDHB subunit. Its mutation leads to the appearance of the paraganglioma syndrome ${ }^{12}$. Up to 26 different mutations have been described in the SDHD gene that are related to the appearance of paragangliomas in the head and neck, with the most common being a deletion in chromosome 11q, which is more important in familial $(86 \%)$ than in non-familial forms $(22 \%)^{12-14}$. The familial form is of the autosomal dominant type, with higher susceptibility for being inherited from the father, which is why it is considered as a maternal imprinting ${ }^{13}$. In the $\mathrm{Ne}$ therlands, familial paragangliomas in the head and neck have been linked to mutations in L139P and $\mathrm{D}_{2} \mathrm{Y}^{16}$, while in the USA, mutations in $\mathrm{P} 81 \mathrm{~L}$ and R38 $\mathrm{X}^{13,14}$ have been observed with higher incidence, which has made for the P81L mutation to be used as a screening method for familial paragangliomas of the head and neck, where mutation in the SDHD gene occurs in $50 \%$ of cases, with $20 \%$ of them being caused by mutations in SDHB, and without mutations in the SDHC gene being observed. Sporadic paragangliomas of the head and neck have also shown an important role of complex II mutations; in the Netherlands, up to $36 \%$ of patients carry the mutation, while in the US it has been found only in $8 \%$ of patients, 
Table 1. Altitude of the place of residence of patients with carotid body tumors

\begin{tabular}{lcc}
\hline Population & Altitude (m a.s.I.) & No. of patients \\
\hline Mexico city & 2240 & 16 \\
State of mexico & 2670 & 13 \\
Toluca & 2600 & 2 \\
Zacatecas & 2496 & 2 \\
Puebla & 2147 & 2 \\
Sal luis potosí & 1860 & 1 \\
Guadalajara & 1570 & 1 \\
\hline
\end{tabular}

and among these, the SDHD gene in $5 \%$ and the SDHB gene in $3 \%^{11,14,16}$.

A gene is a very small part of any chromosome. The DNA fragment that contains the gene of interest is identified by a key property that distinguishes it from other DNA fragments: its sequence. If at least one part of the sequence of the DNA segment to be cloned is known, the number of copies of this DNA segment can be amplified by means of polymerase chain reaction $(\mathrm{PCR})^{17,18}$.

PCR was developed by Kary B. Mullis in 1987 and functions by amplifying a DNA segment using DNA polymerase and two specific oligonucleotides. It is a cyclic process where both DNA chains are denatured by heat; subsequently, small oligonucleotide segments are aligned in a DNA chain, and with the help of DNA polymerase, a new chain is synthesized, with this process taking place in different cycles to amplify the sequence. PCR has sufficient sensitivity to detect and amplify a single DNA molecule in almost any type of sample, such as blood, cerebrospinal fluid, urine, buccal smear, etc. It has uses in archeology, paleontology, forensic medicine, epidemiology, prenatal diagnosis and a wide variety of pathologies; in this case, it will be used to detect a mutation ${ }^{18,19}$.

The purpose of this study is to determine whether the p81L mutation in the SDHD gene (11q23) is present in patients undergoing CBT resection in our population.

\section{Method}

A cross-sectional, observational study was carried out. From the database, 144 patients undergoing surgery for CBT resection with histopathological confirmation were identified from January 2010 to June 2015. Twenty-five patients who accepted having a blood sample taken by signing an informed consent were chosen. Venous blood was processed at the hospital genetics laboratory and real-time PCR was performed using an automated system, looking for the $\mathrm{p} 81 \mathrm{~L}$ mutation in the SDHD gene. This system generates a wave by means of which knowing the wild sequence (which corresponds to a normal genotype) and the sequence in case of mutation (which corresponds to a pathological genotype) is possible, either in homozygous or heterozygous state. The results were analyzed with descriptive statistics using central tendency and dispersion measures with the SPSS statistical package.

It should be considered that, since this is a search for mutations already reported in other populations, which affect specific domains of the protein with a characteristic pathological phenotype and that therefore do not correspond to polymorphisms, considering controls is not necessary.

\section{Results}

Twenty-five patients were included, out of which 23 were females (92\%), with a female/male ratio of 11.5: 1 . Average age was 55.5 years (range: 28-81 years).

According to the Shamblin classification, $8 \%$ of CBTs in our series were type I, 52\% type II, and $40 \%$ type III; of the latter, one case required tumor embolization prior to its resection.

The most common place of residence was Mexico City, followed by the State of Mexico, Toluca, Zacatecas, Puebla and Guadalajara (Table 1).

Two patients $(8 \%)$ had a family history of CBT (one case the father and another a brother); $92 \%$ had sporadic $\mathrm{CBT}$.

In 20\% (5 cases), CBT was bilateral, 16\% (4 cases) had one tumor in another region (with all being benign, in the thyroid gland, breast, colon and ovary), and in no case was it associated with another type of paraganglioma.

The p81L mutation was found in the SDHD gene (11q23) in $16 \%$, with the mutation being heterozygous in all four cases; in 19 patients, homozygous state for the normal variant of the gene was found and, in two patients, determining the genotype with the sequence used for analysis was not possible (Fig. 1).

\section{Discussion}

The hypoxia that patients living in places with an altitude higher than $1500 \mathrm{~m}$ above sea level are subjected to is a known risk factor. In the case of our study, all patients have lived in cities above $1500 \mathrm{~m}$ 


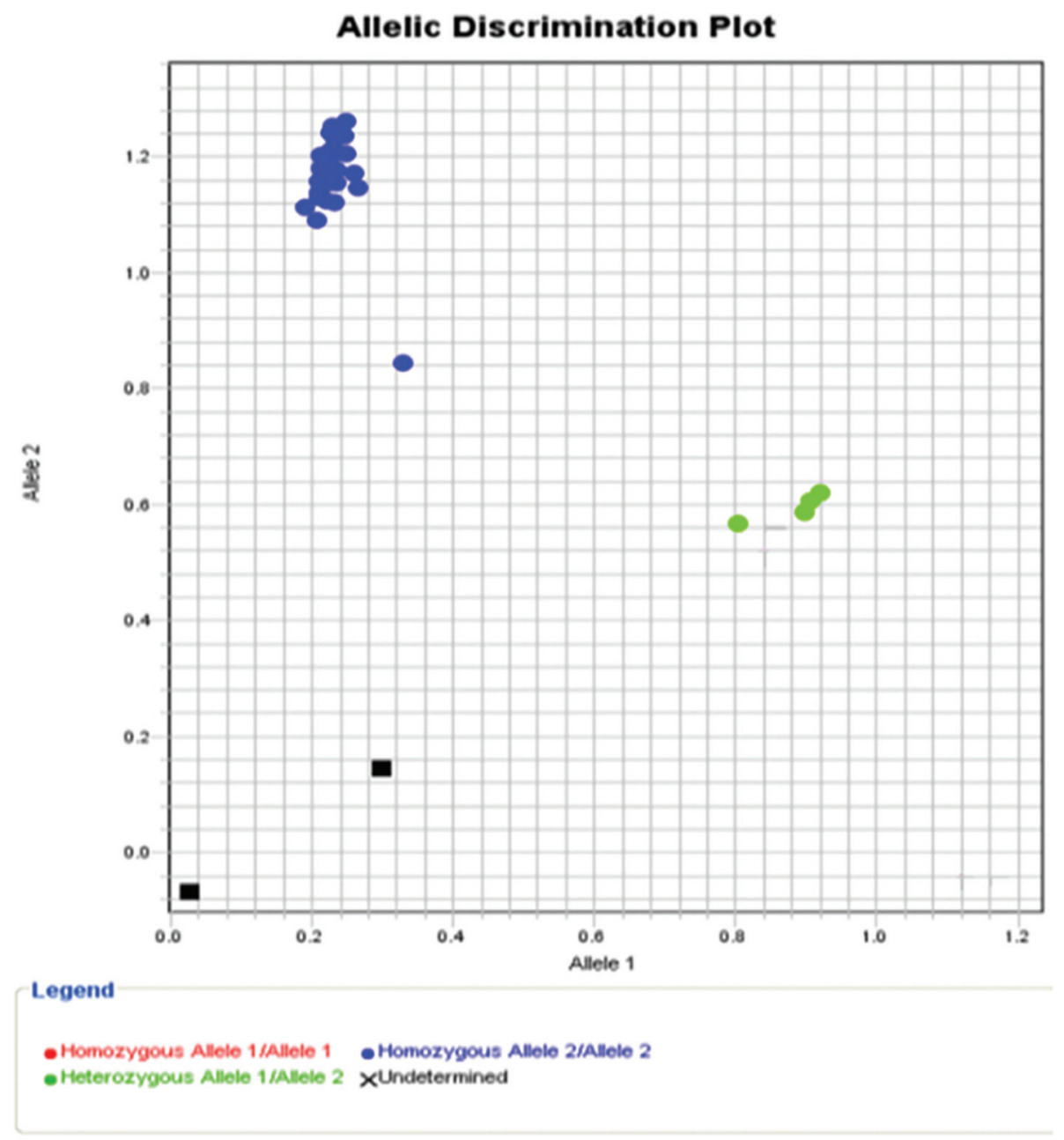

Allele 1: corresponds to the sought mutation, which translates into $L$ in position 81 of the protein

Allele 2: corresponds to the $\mathrm{P}$ normal variant in position 81 of the protein.

Figure 1. Proportion of patients with the p81L mutation in the $\mathrm{SDH}$ gene.

throughout their lives, and the majority (64\%) live in Mexico City. Only two patients (8\%) had a family history, and thus $92 \%$ were classified as sporadic.

Searching for the P81L mutation was decided because it is used as a screening method for familial paragangliomas of the head and neck in the USA ${ }^{14}$ and because this population is closer to ours, although not necessarily representative of similar genetic variants, which is why the fact of carrying out the present study provides knowledge of one more ethnic group in the research on this type of tumors.

A history of other tumors was found in $16 \%$, but in none of these patients was the $\mathrm{p} 81 \mathrm{~L}$ mutation detected.

The p81L mutation was present in $16 \%$ of all our patients, with the incidence being higher than in the US population, where $8 \%$ is reported. All patients were heterozygous for the mutation, which represents a $50 \%$ likelihood for the mutation being inherited by their children.

The presence of the mutation did not increase the risk of malignancy; in fact, no patient showed malignancies in the histopathological report.

Finding a difference with that which has been reported in other countries regarding the presence of the P81L mutation and its association with the development of paragangliomas in a Mexican population group provides new knowledge, and opens the opportunity for new research to find out whether there is any specific genomic variability in the Mexican population that facilitates the development and timely detection of paragangliomas. 


\section{Conclusion}

The results of this study serve to identify that, although hypoxia as a result of the altitude of the place of residence is a risk factor in our environment, it is not the only determinant for the appearance of the tumor, and that our population is also susceptible to changes in genetic material associated with predisposition for its development. It is necessary to consider that despite having demonstrated in our study population that the P81L mutation is found in patients who have developed paragangliomas, it is imperative to continue with the study of other genetic variants that may be involved in the pathophysiology of paragangliomas in the Mexican population, whereby in the future we could not only asymptomatically determine the possibility of developing the tumor, but also would be able to have an early and accurate approach to the management of patients, complemented with an adequate genetic counseling that enables a comprehensive approach to affected families and with sufficient scientific tools to develop preventive and timely treatment measures.

\section{Ethical responsibilities}

Protection of people and animals. The authors declare that no experiments have been conducted on humans or animals for this research.

Confidentiality of data. The authors declare to have followed the protocols of their work center on the publication of patient data.

Right to privacy and informed consent. The authors have obtained informed consent from the patients and/or subjects referred to in the article. This document is in possession of the corresponding author.

\section{Funding}

No funding was received for its performance. This study was carried out at the IMSS.

\section{Conflict of interests}

The authors declare not having any conflicts of interests relevant to this article.

\section{References}

1. Shamblin WR, ReMine WH, Sheps SG, Harrison EG. Carotid body tumor (chemodectoma). Clinicopathologic analysis of ninety cases. Am J Surg.1971;122:732-9.

2. Glenn MM, Virendra IP. Carotid Artery. Carotid body tumors and other disorders. En: Cronenwett J, Johnston W, editores. Rutherford's Vascular surgery. $8^{\text {th }}$ ed. Philadelphia: Elsevier; 2014. p. 1598-614.

3. Rodríguez CS, López GJ, Labastida AS. Carotid body tumors in inhabitants of altitudes higher than 2000 meters above sea level. Head Neck. 1998:20:374-8.

4. Pellitteri PK, Rinaldo A, Myssiorek D, Gary JC, Bradley PJ, Devaney KO, et al. Paragangliomas of the head and neck. Oral Oncol. 2004;40:563-75.

5. Balcazar A, López C, Soto I. Tumor del cuerpo carotídeo de altura. Revisión de 35 años. Conceptos actuales, manejo de 333 tumores y nueva clasificación. Técnicas endovasculares. 2011;XIV:3927-39.

6. Torres PF, Gómez AF, Guzmán PC, Mendoza PJ, Labastida AS. Carotid body tumor. Analysis of 96 cases. Rev Invest Clin. 1991;43:119-23.

7. Luna OK, Rascon OM, Villavicencio VV, Herrera GA. Does Shamblin's classification predict postoperative morbidity in carotid body tumors? A proposal to modify Shamblin's classification. Eur Arch Otorhinolaryngol. 2006;263:171-5.

8. Persky MS, Setton A, Niimi Y, Hartman J, Frank D, Berenstein A. Combined endovascular and surgical treatment of head and neck paragangliomas a team approach. Head Neck. 2002;24:423-31.

9. Martínez C, Sánchez B, Arriola H, Laven R, Bacelis R. Paragangliomas carotídeo, yugulares y aórticos. Experiencia de 25 años. Angiologia. 2005;33(4);110-3

10. Luna K, Rascon M, Villavicencio V, Granados G, Herrera G. Carotid body tumors: review of a 20-year experience. Oral Oncology. 2005;41:56-61.

11. Baysal BE. Hereditary paraganglioma targets diverse paraganglioma. J Med Genet. 2002;39:617-22.

12. Fishbein L, Nathanson K. Pheochromocytoma and paraganglioma understanding the complexities of genetic background. Cancer Genetics. 2012;201:1-11.

13. Sevilla MA, Hermsen MA, Weiss MM, Grimbergen A, Balbín M, Llorente $\mathrm{JL}$, et al. Chromosomal changes in sporadic and familial head and neck paragangliomas. Otolaryngol Head Neck Surg. 2009;140:724-9.

14. Mhatre AN, Li Y, Feng L, Gasperin A, Lalwan AK. SDHB, SDHC and SDHD mutation screen in sporadic and familial head and neck paragangliomas. Clin Genet. 2004;66;461-6.

15. Bikhazi PH, Messina L, Mhatre AN, Goldstein JA, Lalwani AK. Molecular pathogenesis in sporadic head and neck paraganglioma. Laryngoscope. 2000;110:1346-8.

16. Taschner PE, Jansen JC, Baysal BE, Bosch A, Rosenberg EH, Bröcker-Vriends $\mathrm{AH}$, et al. Nearly all hereditary paragangliomas in the $\mathrm{Ne}$ therlands are caused by two founder mutations in the SDHD gene. Genes Chromosomes Cancer. 2001;31:274-81.

17. Eng C, Kiuru M, Fernández A, Lauri A. A role for mitochondrial enzymes in inherited neoplasia and beyond. Nat Rev Cancer. 2003:3:193-202.

18. Boehm CD. Use of polymerase chain reaction for diagnosis of inherited disorders. Clin Chem. 1989;35:1843-8.

19. Fruhmann J, Geigl JB, Konstantiniuk P, Cohnert TU. Paraganglioma of the carotid body: treatment strategy and SDH-gene mutations. Eur $\mathrm{J}$ Vasc Endovasc Surg. 2013;45:431-6. 